of respiratory failure by tracheotomy and intermittent positive pressure respiration. There may be some disagreement over the frequency that this form of treatment should be used but there can be little doubt that it is life-saving in patients suffering from difficulty in swallowing as well as in breathing. The knowledge gained at Copenhagen has proved invaluable to other workers in this field and it is well presented in this book.

There are chapters on various aspects of the acute stage of the illness such as the performance of a tracheotomy and of bronchoscopy, the types of artificial ventilation available, the physiotherapy that should be given and the complications that may ensue. Problems that may arise when the patient has begun to recover are also dealt with. These include the removal of the tracheotomy tube and the weaning of the patient from artificial respiration. There are also chapters in such subjects as the laboratory control of gas exchange and the electrocardiographic changes in acute poliomyelitis. Finally there is a report on the autopsy findings.

This book can be recommended to anyone likely to be called upon to treat patients with poliomyelitis and they will find much that is of value in this record of the work of those who were faced with an almost unique epidemic.

N.S.G.

\section{DIAGNOSIS AND TREATMENT OF VASCULAR DISORDERS. ANGIOLOGY}

Edited by Saul S. SAMuel, A.M., M.D., F.A.C.A., F.A.C.C. Pp. ix +621 , with 367 illustrations. London: Bailliere, Tindall and Cox Ltd. 1956. I $28 \mathrm{~s}$.

This book is a survey by a group of authors drawn, for the most part, from the United States, but including Professor Boyd, of Manchester, and one of his associates. It is evident that the editor and his contributors have aimed to cover the whole field contained in the title, so that the book opens with chapters devoted to the anatomy and physiology of the peripheral vessels both in health and in states of disease. The chapter dealing with the examination of the patient covers a very wide range of methods of clinical and ancillary study, besides analysing the symptomatology encountered in these patients in some detail. The chapter on angiography, rather unexpectedly describing angiocardiography for good measure, is followed by the body of the book describing in turn the various disorders of the peripheral circulation, arterial, venous and lymphatic. The chapter dealing with arterial injuries covers the experience derived from. recent wars in detail and the resulting advances very well and this is so of the chapters covering the major vascular diseases.

However, the details of surgical treatment have been dismissed to other sources by the editor, so that the book is not so much intended for a surgeon as for reference purposes in a more general field. The extensive range of analysis of symptoms and of methods of study are, in fact, rather wider than a clinician is likely to require and it seems rather easy to become lost in the detail so generously supplied.

The actual format of the book cannot be criticized. In type, quality of paper and in the excellence of the illustrations the book is typical of this publisher's publications.

\section{MEDITATIONS ON MEDICINE AND} MEDICAL EDUCATION PAST AND PRESENT

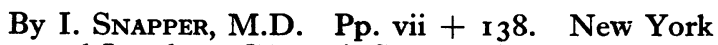
and London: Grune \& Stratton. 1956. \$3.75.

From an extensive review of medicine in the Netherlands in the $17^{\text {th }}$ and 18 th centuries the author, himself born and educated in Amsterdam, traces the influence of European ideas in the development of American medical schools and discusses the evolution of modern methods of teaching. Over a third of the book is devoted in great detail to the early colonists, which is perhaps out of proportion, but will appeal, as will the whole book, to those interested in the history of medicine.

\section{A.S.}

\section{LIFE OF SIR JOHN BLAND SUTTON}

By W. R. BETT, M.R.C.S. Pp. viii + Ioo, with 5 illustrations. Edinburgh: E. \& S. Livingstone Ltd. 1956. 20 .

A surgeon whose interests cover not only clinical and pathological research in his chosen profession, but take in almost the whole field of nature and range from astronomy to travel and authorshipe provides his biographer with an abundance of material of which Dr. Bett makes full use. The test is enlivened by descriptions of those unrehearsed incidents which throw so much light on the character of a man, and by well-chosen quotations from Bland Sutton's speeches and writings to illustrate his love of the striking phrase. One's interest is retained throughout this readable little book.

A.S.

\section{NEUROLOGY AND PSYCHIATRY IN CHILDHOOD}

Proceedings of the Association for Research I in Nervous and Mental Disease, Vol. XXXIV. Edited by R. McInTosh, M.D., and C. C. HARE, M.D. Pp. xii +504 , with 63 illustrations. London: Baillière, Tindall \& Cox Ltd. 1956. 88 s.

The annual research publications of the Association for Research into Nervous and Mental Disease will be well known to readers. This 34th volume maintains the high standard of its predecessors, and presents in 14 chapters a very broad spectrum of the neurological disorders in childhood. The chapters on the radiological features of 